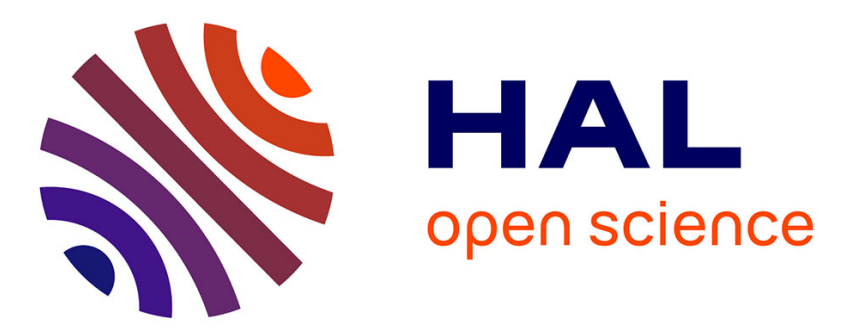

\title{
How Do Richness and Composition of Diet Shape Trace Metal Exposure in a Free-Living Generalist Rodent, Apodemus sylvaticus
}

\author{
Shinji Ozaki, Clémentine Fritsch, Benoît Valot, Frédéric Mora, Thierry \\ Cornier, Renaud Scheifler, Francis Raoul
}

\section{To cite this version:}

Shinji Ozaki, Clémentine Fritsch, Benoît Valot, Frédéric Mora, Thierry Cornier, et al.. How Do Richness and Composition of Diet Shape Trace Metal Exposure in a Free-Living Generalist Rodent, Apodemus sylvaticus. Environmental Science and Technology, 2019, 53 (10), pp.5977-5986. 10.1021/acs.est.8b07194 . hal-02316627

\section{HAL Id: hal-02316627 \\ https://hal.science/hal-02316627}

Submitted on 7 Feb 2022

HAL is a multi-disciplinary open access archive for the deposit and dissemination of scientific research documents, whether they are published or not. The documents may come from teaching and research institutions in France or abroad, or from public or private research centers.
L'archive ouverte pluridisciplinaire HAL, est destinée au dépôt et à la diffusion de documents scientifiques de niveau recherche, publiés ou non, émanant des établissements d'enseignement et de recherche français ou étrangers, des laboratoires publics ou privés. 


\section{How do richness and composition of diet shape trace}

$4 \quad$ Shinji Ozaki ${ }^{* \dagger}$, Clémentine Fritsch ${ }^{\dagger}$, Benoit Valot ${ }^{\dagger}$, Frédéric Mora $^{\ddagger}$, Thierry Cornier ${ }^{\S}$, Renaud

$6 \uparrow$ Laboratoire Chrono-environnement, UMR 6249 CNRS/Université Bourgogne Franche-Comté

\section{KEYWORDS}

14 Food identification; Metabarcoding; Trophic transfer; Wildlife; Salicaceae. 


\section{TM contaminated site}

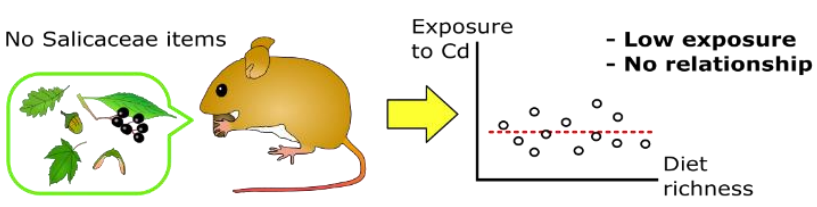

16

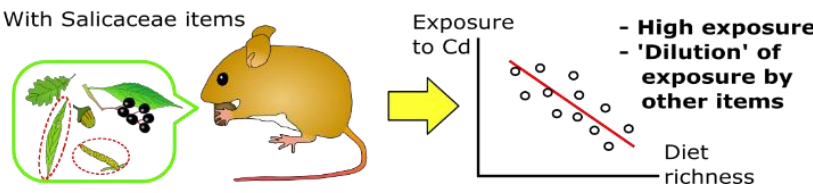


19 Exposure of terrestrial mammals to chemical contaminants like trace metals (TMs) is considered

20 to be mainly based on trophic transfer. Although relationships between TM transfer to animals

21 and identity of contaminated food have been studied, the variation of the TM transfer with

22 respect to diet diversity has been poorly documented. In this study, the oral exposure to TMs of

23 wood mice Apodemus sylvaticus was investigated with respect to both the number of different

24 items, i.e. diet richness, and the identity of items determined by metabarcoding from their

25 stomach content, i.e. diet composition. The results showed that consuming Salicaceae, a known

26 cadmium accumulator plant family, significantly increased exposure to cadmium and zinc.

27 However, an increase in diet richness minimized exposure to cadmium when mice consumed

28 Salicaceae items. This strongly suggests that TM accumulator items can lead to a high oral

29 exposure to TMs but that such high exposure due to TM accumulator items can be "diluted" by

30 diet richness due to other low accumulator items. Our results clearly indicate that both the

31 presence of certain items in the diet and diet richness are important determinants of exposure to

32 TMs in generalist animals, which matches the predictions of the "diet dilution hypothesis". 


\section{Introduction}

34 Trace metals (TMs) are naturally occurring substances in trace amounts, in a proportion below

$350.1 \%$, in natural media. ${ }^{1}$ Although some of them are essential for life, TMs can pose risks to both

36 wildlife and human health at elevated concentrations resulting from anthropogenic activities. ${ }^{2}$

37 The assessment and the mitigation of environmental risk of TM contamination of ecosystems

38 require both a sound understanding and an accurate estimate of the exposure of free-living

39 organisms to TMs. The exposure of wild mammals to TMs occurs mainly through consumption

40 of contaminated food. ${ }^{3}$ The composition of diet has been focused on as an important aspect of

41 the variation of exposure of small mammals to TMs. For instance, earthworms or snails,

42 organisms that may accumulate TMs at high concentrations in their tissues, have been considered

43 to be important contributors for exposure to TMs in mammals consuming them. ${ }^{4-6}$ However,

44 mammals can consume simultaneously numerous different items. Although ingesting some metal

45 accumulator items leads to an increase in exposure, many other less TM accumulator items could

46 reduce total TM concentrations in the diet. A wide variety of items consumed may result in two

47 opposite effects: increased opportunity of consuming TM accumulators or reduced TM

48 concentrations of ingested food. However, few studies have assessed the accurate diet

49 composition and richness related to the TM contamination in mammals, ${ }^{7}$ and, to our knowledge,

50 no study have investigated the relationships between the oral exposure of mammals to TMs and

51 such diet richness.

52 The accurate determination of items actually consumed is a major challenge in wildlife diet

53 assessment because identification at high taxonomic resolution is almost impossible with

54 classical macro- or microscopy-based methods. However, current technological development

55 such as high-throughput next generation sequencing has led a rise of new DNA-based techniques 
as a powerful approach for multispecies identification using degraded DNA extracted from wide

57 range of environmental samples, i.e. soil, water or feces (eDNA metabarcoding). ${ }^{8-12}$ The

58 efficiency of the eDNA metabarcoding has been demonstrated in diet analysis in various

59 mammals. ${ }^{13-17}$ This method is expected to identify in detail the diet composed of numerous items

60 in generalist small mammals like the wood mouse (Apodemus sylvaticus), ${ }^{18-21}$ a rodent widely

61 spread in Europe ${ }^{22}$ and frequently used for monitoring of environmental metal pollution, $5,6,23-25$

62 and then to allow associating the oral exposure of the rodent to TMs and both the composition

63 and the richness of their diet.

64 The present study analyzed the relationship between exposure to TMs of wood mice captured

65 along a gradient of soil TM contaminations in a smelter-impacted area and their diet determined

66 by metabarcoding from their stomach content. We hypothesized that (1) the consumption of

67 (hyper-)accumulator items like earthworms induces a high exposure of small mammals to TMs

68 and that (2) such exposure is shaped by the diet richness due to a "dilution" effect where high

69 exposure related to accumulator items is reduced by the consumption of less accumulator items

70 in case of high diet richness.

$72 \quad$ Materials and methods

73 Study Area. The study area was located in Northern France (Noyelles Godault, Hauts-de-

74 France, France). Due to metal containing dust released from the former lead $(\mathrm{Pb})$ and zinc $(\mathrm{Zn})$

75 smelter "Metaleurop Nord", the soils surrounding the smelter are highly contaminated by TMs,

76 especially cadmium $(\mathrm{Cd}), \mathrm{Pb}$ and $\mathrm{Zn} .^{26-29}$ Total TM concentrations in soils of woody habitats in

77 an area of $40 \mathrm{~km}^{2}$ around Metaleurop Nord range from 0.1 to $237 \mathrm{mg} \mathrm{kg}^{-1}$ of dry soil for Cd, from

7816 to $7331 \mathrm{mg} \mathrm{kg}^{-1}$ for $\mathrm{Pb}$, and from 44 to $7264 \mathrm{mg} \mathrm{kg}^{-1}$ for $\mathrm{Zn}$, which dramatically exceed the 
79 concentrations in a reference site $\left(0.9-2,43-200\right.$ and $89-278 \mathrm{mg} \mathrm{kg}^{-1}$ of dry soil for $\mathrm{Cd}, \mathrm{Pb}$, and

$80 \mathrm{Zn}$, respectively) from the same region. ${ }^{30}$ The present study was undertaken on seven sites of

$81500 \mathrm{~m} \times 500 \mathrm{~m}$, located along a soil contamination gradient and composed of three types of

82 dominant habitats (for details see Supporting Information Table S1). TM concentrations in soils

83 of woody habitats, expressed as $\mathrm{mg} \mathrm{kg}^{-1}$ of dry soil, were based on data published in Fritsch et

84 al..$^{30}$ and used for statistical analyses.

Sample Collection. Rodent Trapping. Wood mice were captured in spring (April) and in

87 autumn (September and October) 2012, in accordance with current French legislation about

88 ethics and use of animals in research. In each season and each site, 10 trap lines composed of 10

89 small break-back traps (3 m spaced each) were used with peanut as rodent's bait following

90 Fritsch et al. ${ }^{31}$ All trap lines were set in woody habitats and their position was geo-referenced.

91 The trap lines were checked in the morning for 3 consecutive days and re-set and/or re-baited, if

92 necessary. Captured animals were immediately frozen and stored at $-20^{\circ} \mathrm{C}$ for further analyses in

93 the laboratory. For this study, 200 wood mice composed of 95 females, 103 males and two

94 individuals whose sex could not be identified were used. The sex-ratio was not significantly

95 different from 1:1 (chi-squared $=0.32, p$-value $=0.57)$. One hundred and three mice were taken

96 in spring and 97 in autumn. The ratio between the two seasons was not significantly different

97 from 1:1 (chi-squared $=0.18, p$-value $=0.67)$.

98 Stomach Content Extraction. Stomach content (SC) was extracted with a spatula from each

99 rodent's body thawed at room temperature. After removing remaining bait, each SC was

100 homogenized and split into two aliquots. One aliquot (about $10 \mathrm{mg}$ ) was stored in $95 \%$ ethanol

101 for the metabarcoding analysis. The other was used for measuring TM concentrations which 
102 were used to estimate exposure of mice to metals via the food ingested within the last few hours.

103 The spatula was thoroughly cleaned with disposable tissues, then washed with ultra-pure water

$104\left(18.2 \mathrm{M} \Omega / \mathrm{cm}^{2}\right.$ by Millipore Milli-Q Integral 3) and wiped off with other tissue between each

105 extraction.

106

107 Metal Analysis. The SCs for TM concentration analysis were dried at $50^{\circ} \mathrm{C}$ in an oven until 108 obtaining constant mass. The dried samples were digested in $\mathrm{HNO}_{3}$ (67-69 \%; Fisher Scientific 109 Bioblock, ultratrace quality Optima) with $\mathrm{H}_{2} \mathrm{O}_{2}$ (Fisher Scientific Bioblock) by using Digiprep 110 (SCP Sciences). The samples were then diluted by adding ultra-pure water $\left(18.2 \mathrm{M} \Omega / \mathrm{cm}^{2}\right)$. TM 111 concentrations were measured with an inductively coupled plasma mass spectrometry (ICP-MS:

$112 \mathrm{X}$ Series II, ThermoFischer Scientific) and expressed as $\mu \mathrm{g} \mathrm{g}^{-1}$ of dry mass (DM). Analysis 113 accuracy was checked by using certified reference materials (INCT-OBTL-5: Oriental Basma 114 Tobacco Leaves). Mean and standard deviation of recovery rate for $\mathrm{Cd}, \mathrm{Pb}$ and $\mathrm{Zn}$ were 115 respectively $107.2 \pm 4.7,83.6 \pm 9.6$ and $100.7 \pm 9.1 \%$.

117 Diet Assessment Using Metabarcoding Analysis. DNA Extraction, Amplification and 118 Sequencing. The DNA extraction, amplification and the PCR purification were performed at 119 SPYGEN facilities (www.spygen.com). DNeasy Blood and Tissue Kit (Qiagen GmbH) was used 120 for extracting total DNA, following the manufacturer's instruction. DNA amplification was 121 performed with three sets of primers: primer targeting the P6 loop of the chloroplast trnL (UAA) 122 intron $g / h^{32}$ was used for identifying general plant species, primer targeting a short fragment of 123 mitochondrial 16S gene (16S mtDNA) was for arthropod and mollusk DNA (16SMAV$124 F / 16 S M A V-R)^{16}$, and primer targeting a short region of $16 \mathrm{~S}$ mtDNA for earthworm $(e w D / e w E)^{33}$ 
125 (for details of those primers, see Supporting Information Table S2). PCR amplifications were

126 carried out on Applied Biosystems Veriti 96 Wells (Life Technologies). The amplification was

127 realized in a final volume of $25 \mu \mathrm{L}$ using $3 \mu \mathrm{L}$ of DNA extract. Two PCR replicates were

128 performed per each sample. For the amplification of arthropod and mollusc DNA, $2 \mu \mathrm{M}$ of a

129 blocking primer for mammal's DNA $\left(\operatorname{MamMAVB1} 1^{16}\right)$ were added in the PCR mix. The 130 amplification mixture contained $1 \mathrm{U}$ of AmpliTaq Gold DNA Polymerase (Applied Biosystems),

$13110 \mathrm{mM}$ of Tris- $\mathrm{HCl}, 50 \mathrm{mM}$ of $\mathrm{KCl}, 2.5 \mathrm{mM}$ of $\mathrm{MgCl}_{2}, 0.2 \mathrm{mM}$ of each dNTP, $0.2 \mu \mathrm{M}$ of group-

132 specific primers, $0.2 \mu \mathrm{g} / \mu \mathrm{L}$ of bovine serum albumin (BSA, Roche Diagnostic) and ultra-pure

133 water $(18.2 \mathrm{M} \Omega / \mathrm{cm} 2)$ to bring each sample to the final volume. The mixture was denatured at

$13495^{\circ} \mathrm{C}$ for $10 \mathrm{~min}$, followed by 45 cycles of $30 \mathrm{~s}$ at $95^{\circ} \mathrm{C}, 30 \mathrm{~s}$ at $50^{\circ} \mathrm{C}$ for $\operatorname{trn} L-g / h$, at $55^{\circ} \mathrm{C}$ for

$13516 S M A V-F / 16 S M A V-R$ and at $58^{\circ} \mathrm{C}$ for $e w D / e w E$ and $1 \mathrm{~min}$ at $72^{\circ} \mathrm{C}$, followed by a final

136 elongation at $72^{\circ} \mathrm{C}$ for 7 min. Extraction and PCR negative controls were analyzed in parallel in

137 order to monitor potential contamination. After amplification, the samples were purified using a

138 MinElute PCR purification kit (Qiagen $\mathrm{GmbH}$ ). Before sequencing, purified DNA was titrated

139 using capillary electrophoresis (QIAxcel; Qiagen $\mathrm{GmbH}$ ). The purified PCR products were

140 pooled in equal volumes, to achieve an expected sequencing depth of 10,000 reads per sample.

141 Libraries were prepared using TruSeq Nano DNA genomic kit (Illumina) and a pair-end

142 sequencing $(2 \times 100 \mathrm{bp})$ was carried out with an Illumina HiSeq sequencer (Illumina) using

143 TruSeq SBS Kit v3 (Illumina) following the manufacturer's instructions. Library preparation and

144 sequencing were performed at Fasteris facilities (www.fasteris.com).

145 Bioinformatics. Reads were handled by the software Mothur pipeline. ${ }^{34}$ Forward and reverse

146 reads were assembled in contig sequences. Sequences were filtered based on length (20-90bp for

$147 \operatorname{trn} L-g / h ; 36-38 \mathrm{bp}$ for $16 S M A V ; 69-81 \mathrm{bp}$ for $e w D / e w E$ ), homo-polymer (less than 10 nucleotides) 
148 and no ambiguous nucleotides. After de-replication (count occurrence of each different 149 sequence), only unique sequences with a minimum count of 10 (sum of all samples) were used

150 for further analyses. The data was applied both to diet richness estimation and to identification of 151 food composition.

152 Diet Richness Estimation. Molecular Operational Taxonomic Units (MOTUs) were used for 153 measuring diet richness. Sequences were clustered for each primer with average neighbor 154 algorithm using Needlman-Wunsch distance. The cutoff values were chosen as effective 155 clustering on the basis of relationships between number of clusters and distance: $0.032,0.042$, 156 and 0.034 for sequences obtained from the primers trnL-g/h, $16 S M A V$ and $e w D / e w E$, 157 respectively. After using an occurrence of 100 as a threshold to remove background sequencing 158 data, the sequence data were converted into presence/absence of MOTUs because the number of 159 sequences from degraded DNA is likely not proportional to the biomass of each taxa really 160 eaten. $^{35}$

161 Food Composition. For the detail of food identification method, see Ozaki et al. ${ }^{36}$ Briefly, each 162 sequence extracted from SCs (i.e., query sequence) was compared with reference sequences of 163 species recorded in the study area, ${ }^{36}$ taken from the GenBank sequence database 164 (www.ncbi.nlm.nih.gov/genbank). When query sequence matched with more than one reference 165 sequence, query sequences were gathered into one group composed of the corresponding species, 166 and then gathered at the family level. The sequences were finally converted into 167 presence/absence of each plant family in SCs. Invertebrate resources in the field were identified 168 mainly at family level, which could not allow to identify invertebrate food. We used only the 169 presence/absence of arthropod and mollusk items (referred to as only "arthropod" hereinafter) 170 and earthworm items in SCs as food composition. 
172 Statistical Analysis. Statistical analyses were carried out on the 200 mice. As TM

173 concentrations in SCs could be influenced both by soil TM contamination levels through food

174 and ingestion of soils, ${ }^{37,38}$ we aimed to reduce potential bias related to the level of environmental

175 contamination when quantifying oral exposure as follows. For each TM, a linear positive

176 relationship was observed between the concentrations in SCs and in soils of the woody habitat

177 where each mouse was captured (logarithmically transformed concentrations, p-values of

178 ANOVA $<0.05$; for details see Supporting Information Figure S1). The residuals of these linear

179 models were referred to as "exposure" hereinafter and used in following statistical analyses.

180 Exposure to TMs and items consumed. The exposure was compared between the two seasons, 181 and presence and absence of each identified item in SCs by the non-parametric Wilcoxon-Mann182 Whitney test. Among the identified items consumed by wood mice (for details see Ozaki et al. ${ }^{36}$ ), 183 only items whose occurrence was higher than 10 in the diet of the 200 mice were used in this 184 comparison between presence/absence of items to ensure statistical power of tests: arthropods, 185 earthworms, Betulaceae (e.g. genura Alnus, Betula), Fagaceae (Fagus), Oleaceae (Fraxinus), 186 Poaceae (Arrhenatherum, Holcus Lolium, etc), Rosaceae (Crataegus), Sapindaceae (Acer), 187 Salicaceae (Populus, Salix), and the sequence group composed of Adoxaceae (Sambucus), 188 Asteraceae (Hedera) and Cornaceae (Cornus) items (referred to as "group AAC" hereinafter). 189 When exposure was significantly related to several variables tested, we used conditional 190 inference trees $\left(\mathrm{CIT}^{39}\right)$ for ranking their importance for the exposure to TMs. This is a recursive 191 binary partitioning analysis that studies significant univariate splits over all possible splitting 192 variables. The splitting variable the most significantly associated to response value will be 193 chosen. Those steps are recursively performed to the two split data, until no significant 
194 difference are observed. Permutation tests by Strasser and Weber ${ }^{40}$ are applied for the splitting 195 tests. In this study, CIT was performed across binary partitioning variables: season (spring or 196 autumn) and the presence/absence of the 10 types of items mentioned above. Sites were 197 considered to be random effects for exposure in the Wilcoxon-Mann-Whitney test and CIT 198 because of potential effects linked to each site. Those tests were executed for the residuals of the 199 random effect model, i.e. the model with only site as random effect. As all items were used as 200 partitioning variables without taking into account the result of each Wilcoxon-Mann-Whitney 201 test, $p$-value of CIT was not adjusted by Bonferroni correction.

202 If CIT suggested an influence of TM of hyper-accumulator items, we then checked whether 203 exposure was explained by the importance of the given items in the diet. In general, ascertaining 204 abundance information using metabarcoding of environmental DNA (eDNA) still lacks 205 consistent evidence due to multiple factors distorting the eDNA-biomass relationship, such as 206 difference in origin (species, organ, etc.) and stability of eDNA and primer bias in 207 amplification. ${ }^{41}$ This is particularly true when comparison of different taxa, identified using 208 different primers, is an objective. We calculated the proportion of DNA reads of hyper209 accumulator items suggested by CIT in the SC over the total number of DNA reads. In doing so, 210 we did not expect strong bias in comparison because (i) each hyper-accumulator was identified 211 using a single primer and (ii) we assumed that its DNA stability would remain comparable 212 among samples. We therefore assumed that changes in the biomass of a hyper-accumulator 213 ingested would be reflected by changes in the proportion of its DNA sequences over the total 214 number of DNA sequences.

215 Relationships between exposure and the proportion of sequences of the given hyper216 accumulator items within SCs containing the given items was analyzed using a linear mixed 
217 model with the site as random effect. The variations explained by the fixed and random effects

218 were estimated by marginal $R^{2}\left(R^{2}\right)$ and conditional $R^{2}\left(R^{2}\right)$, respectively. ${ }^{42}$ Relationships

219 between the proportion of the given items and diet richness was also checked using a linear 220 mixed model.

221 Diet of wood mice. Co-occurrence of items, which could mislead into a fault interpretation in 222 the relationships between exposure and a given item consumed, was checked by CIT: Frequency 223 of occurrence of each plant item was assessed across season and the presence/absence of the 224 other plant items in SCs. In addition, relationship between occurrence of items and TM 225 concentration in soils was analyzed by generalized linear models with logit function for binary 226 data. Probability for occurrence of a given item was compared to a gradient of each TM 227 concentrations in soils. Significance of each model was checked by the likelihood-ratio test 228 compared to the null model.$^{43}$ Meanwhile, diet richness across season was checked by the 229 Wilcoxon-Mann-Whitney test. Each correlation between TM in soils and diet richness was 230 analyzed by the non-parametric Spearman correlation test.

231 Exposure to TMs and diet richness. Number of plant, arthropod, and earthworm MOTUs in SC 232 were defined as three independent diet richness, and the sum of the three richness as total diet 233 richness. A linear mixed model with the site as random effect was built and analyzed for the 234 exposure to each TM with respect to the total diet richness and to the three richness. The 235 relationships between the exposure, the diet richness, and the presence of specific items were 236 analyzed by model-based recursive partitioning $\left(\mathrm{MOB}^{44}\right)$. The principle of $\mathrm{MOB}$ is the same as 237 CIT, i.e. recursive binary partitioning of data by statistical approach, but each terminal node is 238 associated to a model rather than to a variable like CIT. After establishing a model and deciding 239 partitioning variables to involve, MOB assesses whether the model parameters are stable with 
240 respect to partitioning variables. If there is a significant instability, ${ }^{45,46}$ the analysis selects the

241 partitioning variable associated with the highest instability and computes the split point (for

242 quantitative variables) or split class (for qualitative variables) which optimizes the parameter

243 stability. Those steps are repeated in the two split data, until instability is not significant. Finally,

244 significance of explanatory variables in each terminal node was assessed by a type III ANOVA

245 ( $p$-value node $)$. In our case, MOB was executed on the basis of mixed linear models. ${ }^{47}$ Partitioning

246 variables were the same as for CIT, and $p$-value of partitioning test was not adjusted. The

247 variations explained by the fixed and random effects of the whole model were estimated by $\mathrm{R}^{2} \mathrm{~m}$

248 and $\mathrm{R}^{2}$, respectively. ${ }^{42}$ Explanatory value of the fixed effects in a terminal node $\left(\mathrm{R}^{2}\right.$ node) was also

249 calculated.

250 All statistical analyses were computed using the statistical software R (ver. 3.4.2; R

251 Development Core Team). The mixed linear models were carried out based on "lme" function in

252 "nlme" package. CIT was performed by "ctree" function in "partykit" package, and MOB based

253 on linear mixed models was performed by "Imertree" function in "glmertree" package.

$255 \underline{\text { Results }}$

256 Diet of mice. Occurrence of items. The frequency of occurrence of plant, arthropod and 257 earthworm items in stomach content of mice is $96.5,72.5$, and $27.0 \%$, respectively. No 258 significant difference between the two seasons was observed. Frequencies of occurrence of 259 Fagaceae, Oleaceae, Salicaceae, and Sapindaceae items were significantly higher in spring than 260 in autumn ( $p$-value $<0.001$ for each). Conversely, Poaceae and AAC group items were more 261 frequent in autumn ( $p$-value $<0.001$ for each). The details of the results are provided in 262 Supporting Information Table S3. 
263 The frequency of occurrence of each item was also dependent on the presence of other items.

264 In spring, the frequency of occurrence of Salicaceae items in SCs was significantly and 265 negatively related to the presence of Sapindaceae items (Supporting Information Figure S2a; $p$ 266 value $<0.001)$. The frequency of occurrence of Salicaceae items was also significantly and 267 negatively related to the presence of the group AAC items when Sapindaceae items were absent 268 in spring $(p$-value $<0.024)$. This trend was similar for the frequency of occurrence of 269 Sapindaceae items: in spring, the frequency of occurrence of Sapindaceae items was significantly 270 lower when Salicaceae items were present in SCs, followed by the presence of the group $A A C$ 271 items only when Salicaceae items were absent (Supporting Information Figure S2b; $p$-value < 2720.001 and $=0.019$, respectively). The frequency of occurrence of Fagaceae items in autumn was 273 significantly higher when Betulaceae items were present in SCs (Supporting Information Figure 274 S2c; $p$-value $<0.001)$. Frequency of occurrence of Oleaceae items was significantly higher when 275 Sapindaceae items were present in SCs (Supporting Information Figure S2d; $p$-value $<0.01$ ). 276 When Sapindaceae items were absent, the frequency of occurrence of Oleaceae items was higher 277 when Fagaceae items were present in SCs $(p$-value $=0.01)$.

278 Along the gradient of soil TM concentration, the occurrence of both arthropod and earthworm 279 items did not significantly differ (data not shown). The occurrence of both Salicaceae and 280 Fagaceae items significantly reduced along the gradient of soil TM concentrations only in spring 281 (Supporting Information Figure S3a and S3b; $p$-value $<0.05$ for each of the three TMs in soils), 282 whereas the occurrence of Sapindaceae items significantly increased along the gradient 283 (Supporting Information Figure S3c and S3d; $p$-value $<0.05$ ) in both spring and autumn. The 284 occurrence of the group AAC items significantly increased along the gradient only in autumn 285 (Supporting Information Figure S3e; p-value $<0.05$ ). 
Diet richness. Plant, arthropod and earthworm diet richness ranged from 0 to 6 MOTUs

287 (median: 2), from 0 to 9 (median: 2), and from 0 to 3 (median: 0), respectively. Total diet

288 richness, as well as both plant and arthropod diet richness, were significantly higher in autumn

289 than in spring (data not shown, $\mathrm{W}=3463$, $p$-value $<0.001 ; \mathrm{W}=3646, p$-value $<0.001 ; \mathrm{W}=$

$2904190.5, p$-value $=0.04$, respectively). No significant correlation between the three diet richness

291 values was observed, either in spring or in autumn (Supporting Information Figure S4a and S4b).

292 Only plant diet richness in spring significantly decreased along the gradient of TMs in soils

293 (Spearman's $\rho$ from -0.26 to $-0.19, p$-value $<0.05$ for the three TMs; Figure S4a).

294 Exposure to TMs and items consumed. $\mathrm{Cd}, \mathrm{Pb}$ and $\mathrm{Zn}$ concentrations in SCs ranged from 2950.03 to 47.1 (median: 0.93 ), from 0.03 to 194.2 (median: 3.70 ) and from 5.3 to 337.5 (median:

296 71.1) $\mu \mathrm{g} \mathrm{g}^{-1} \mathrm{DM}$, respectively. The TM concentration in SCs and the exposure were significantly

297 higher in spring than in autumn for the three TMs ( $p$-value $<0.05$; for details see Supporting 298 Information Figure S5). The exposure to Cd was significantly higher when Salicaceae items were 299 present in SCs and significantly lower when AAC plants were present in SCs (W = 2559 and 300 5986; $p$-value $<0.05$, respectively; Supporting Information Figure S6a). The exposure to Zn was 301 significantly higher when Salicaceae items or Oleaceae items were present in SCs $(\mathrm{W}=3073$ 302 and 524; p-value $<0.05$, respectively; Figure $\mathrm{S} 6 \mathrm{~b})$. The exposure to $\mathrm{Pb}$ was not influenced by 303 any item consumed.

304 CIT analysis revealed that season was the most important variable influencing the exposure of 305 rodents to $\mathrm{Cd}(p$-value $<0.001)$, followed by the presence of Salicaceae items in SC in spring 306 (Figure 1a; $p$-value $=0.01$ ). The exposure to $\mathrm{Cd}$ was the highest when Salicaceae items were 307 present in SC in spring, followed by when Salicaceae item were absent in spring, and the lowest 308 in autumn. For $\mathrm{Zn}$, season was the most important variable ( $p$-value $<0.01)$, and the presence of 
309 Salicaceae items in SC determined the exposure to $\mathrm{Zn}$ only in autumn (Figure 1b; p-value <

310 0.05). The exposure to $\mathrm{Zn}$ was the highest in spring, followed by when Salicaceae items were

311 present in SCs in autumn, and the lowest when Salicaceae item were absent in SCs in autumn.

312 No significant partitioning variable was observed for exposure to $\mathrm{Pb}$.

313 Only exposure to $\mathrm{Cd}$ was positively explained by the proportion of sequence number of

314 Salicaceae items (Figure 2a; p-value $<0.05$ ). $\mathrm{R}^{2}{ }_{\mathrm{m}}$ and $\mathrm{R}^{2}{ }_{\mathrm{c}}$ were 0.079 and 0.251 , respectively.

315 The proportion of sequence number of Salicaceae items was negatively correlated with diet

316 richness of plant (Figure $2 \mathrm{~b} ; p$-value $<0.01 ; \mathrm{R}_{\mathrm{m}}^{2}=0.154 ; \mathrm{R}_{\mathrm{c}}^{2}=0.280$ ).

317 Exposure to TMs and diet richness. Exposure to $\mathrm{Cd}$ was significantly and negatively 318 correlated, although weakly, only with the diet richness of earthworms $(p$-value $=0.04)$ but not 319 with other richness values $\left(\mathrm{R}_{\mathrm{m}}^{2}=0.021\right.$ and $\mathrm{R}_{\mathrm{c}}{ }_{\mathrm{c}}=0.103$; data not shown). The relationship 320 between exposure to $\mathrm{Cd}$ and the total diet richness was the most significantly conditioned by the 321 presence/absence of Salicaceae items in SCs (the first oval in the upper part of Figure 3a; $p$-value $322<0.001)$. When Salicaceae items were present in SCs, the exposure was negatively correlated 323 with the diet richness (the scatter plot in the lower part of Figure 3a linked to "Salicaceae" by the 324 line with "yes"; $p$-value node $<0.01, \mathrm{R}^{2}{ }_{\text {node }}=0.184$ ). Season also significantly conditioned the 325 relationship only for SCs in which Salicaceae items were absent $(p$-value $<0.01)$. In spring, the 326 presence of earthworm items significantly conditioned the relationship for SCs in which 327 Salicaceae items were absent $(p$-value $=0.03)$. In autumn, the presence of Poaceae items 328 significantly conditioned the relationship for SCs in which Salicaceae items were absent ( $p$-value $329=0.03)$. When both Salicaceae and Poaceae items were absent in SCs in autumn, the exposure 330 was positively correlated with the diet richness $\left(p\right.$-value node $\left.=0.04, \mathrm{R}_{\text {node }}^{2}=0.110\right)$. The other 331 cases showed no significant relationship between the exposure and the total richness. The 
332 relationship between exposure to $\mathrm{Cd}$ and the three diet richness values was the most significantly

333 conditioned by presence/absence of Salicaceae items in SCs (Figure 3b; $p$-value $<0.001$ ). The

334 exposure was negatively correlated with diet richness of plant when Salicaceae items were

335 present in SCs $\left(p\right.$-value $\left._{\text {node }}<0.001, \mathrm{R}_{\text {node }}^{2}=0.220\right)$. Season significantly conditioned the

336 relationship when Salicaceae items were absent in SCs $(p$-value $=0.03)$ but the exposure showed

337 no significant relationship with any diet richness. $\mathrm{R}_{\mathrm{m}}^{2}$ and $\mathrm{R}_{\mathrm{c}}{ }_{\mathrm{c}}$ of the models for the total richness

338 were 0.196 and 0.275 and for the three richness were 0.191 and 0.276 , respectively.

339 No significant relationship was observed between the exposure to $\mathrm{Zn}$ and both the total and the

340 three richness. However, the relationship between the exposure to $\mathrm{Zn}$ and the total diet richness

341 was significantly conditioned by season (Figure 3c; $p$-value $<0.01$ ). The exposure was positively

342 correlated with the total diet richness in autumn $\left(p\right.$-value node $=0.04, \mathrm{R}^{2}$ node $\left.=0.106\right)$. The

343 relationship between the exposure to $\mathrm{Zn}$ and the three diet richness was significantly conditioned

344 by season ( $p$-value $<0.01$ ), followed by the presence of Betulaceae items in SC in autumn

345 (Figure 3d; $p$-value $=0.02$ ). The exposure to $\mathrm{Zn}$ was significantly and negatively correlated with

346 the diet richness of earthworm when Betulaceae items were present in SCs in spring ( $p$-value node

$347=0.01, \mathrm{R}^{2}$ node $=0.687$; it is noteworthy that only two SCs among 12 ones contained 2 different

348 earthworm items). $\mathrm{R}^{2} \mathrm{~m}$ and $\mathrm{R}^{2} \mathrm{c}$ of the models for the total richness were 0.060 and 0.187 and for

349 the three richness were 0.098 and 0.196 , respectively.

350 No significant relationship was observed between the exposure to $\mathrm{Pb}$ and both the total and the 351 three richness. There was no significant conditioning factor for exposure to $\mathrm{Pb}$. 
354 Our study shed light on the role of diet richness and composition of food on the exposure to

355 TMs in a generalist species. Our results revealed that high diet richness reduces exposure to

356 TMs, particularly in case of consumption of at least one hyper-accumulator taxa, which however

357 depends on both the metal considered and type of items consumed.

358 Consuming plant items belonging to Salicaceae family significantly raised the trophic

359 exposure of wood mice to both $\mathrm{Cd}$ and $\mathrm{Zn}$. Although precaution should be taken in interpreting

360 relationships between number of DNA sequences and biomass consumed (e.g. Deiner et al. ${ }^{41}$ ), a

361 high proportion of Salicaceae family plants in food, which may be considered as a proxy of

362 greater biomass of Salicaceae family plants in the SC, also increased exposure to Cd. Our

363 findings indicated that consuming Salicaceae plants items increased trophic exposure of mice to

364 Cd. Salicaceae family actually includes taxa accumulating $\mathrm{Cd}$ to high concentrations in their

365 tissues like leaves (e.g. genera Salix and Populus), ${ }^{48}$ and their importance on the exposure of

366 mammals to $\mathrm{Cd}$ has been suggested. For instance, Nolet et al. ${ }^{49}$ showed positive correlations

367 between $\mathrm{Cd}$ concentrations in tissues (hairs and kidneys) of beavers Castor fiber and in their

368 main food item, bark of genera Salix and Populus. These genera also accumulate Zn. Brekken

369 and Steinnes ${ }^{50}$ argued that genera Salix and Populus could be the most important $\mathrm{Cd}$ and $\mathrm{Zn}$

370 contributors for moose Alces alces in a metal-contaminated area. Migeon et al. ${ }^{51}$ reported higher

371 concentrations of $\mathrm{Cd}$ and $\mathrm{Zn}$ in both leaves and stems of genera Salix and Populus than in the

372 other woody species around Metaleurop Nord. The authors also demonstrated their high

373 bioconcentration factors (i.e. ratio of metal concentrations in leaves and in soils) which reached 2

374 and 1.2 for $\mathrm{Cd}$ and $\mathrm{Zn}$, respectively. Our study confirmed that Salicaceae items were obviously

375 important contributors of $\mathrm{Cd}$ and, to a lesser extent of $\mathrm{Zn}$, to wood mice Furthermore, our results

376 demonstrated that high Cd concentration due to Salicaceae items was "diluted" by other plant 
377 items, potentially less Cd accumulators than Salicaceae items. Such phenomenon was postulated 378 by Boyd $^{52}$ under the name of "diet dilution hypothesis": trophic exposure of vertebrate 379 herbivores to TMs by high metal accumulator plants would be diluted by consuming low 380 accumulator resources. Indeed, high diet richness of plant might lead to dilute the proportion of 381 Salicaceae items in SCs in our analyses. While this possibility has been suggested in other field 382 studies (e.g. Martens and Boyd ${ }^{53}$ ), we clearly demonstrated, to our knowledge for the first time, 383 the validity of this hypothesis under field conditions.

384 However, we failed to identify potential contributor of exposure to $\mathrm{Pb}$. Migeon et al. ${ }^{51}$ 385 demonstrated an interspecific variation of $\mathrm{Pb}$ concentrations in plant tissues over our study area, 386 although less contrasted than for $\mathrm{Cd}$ or Zn. One possibility could be an effect of soil ingested by 387 mice. Quantity of soil ingested by small rodents represents only a few percent of dry mass in the 388 diet, which was quantified to be maximum of $2 \%$ for the white-footed mouse. ${ }^{37}$ Lead 389 bioconcentration factors of woody plants in our study area were very low, ranging from 0.005 to $3900.11,{ }^{51}$ suggesting a low mobility of $\mathrm{Pb}$ towards plants. The same pattern was observed over this 391 area for invertebrates (earthworms, mollusks, arthropods) which exhibited low biota-to-soil 392 concentration ratios for $\mathrm{Pb}$ (mostly lower than 0.1 , and lower than for $\mathrm{Cd}$ and $\mathrm{Zn}$ ). ${ }^{54,55}$ It is thus 393 possible that a large part of $\mathrm{Pb}$ in SCs could be derived from soils and that it may obscure any 394 effect of dietary richness or composition on $\mathrm{Pb}$ concentration in SCs. Effects of geophagy on 395 exposure to $\mathrm{TM}$ and/or accumulation of $\mathrm{TM}$ in animals remain as a further issue that 396 undoubtedly deserves attention.

397 On the other hand, consuming invertebrate items, especially earthworms that are well-known 398 as high TM accumulator species, ${ }^{56}$ did not increase the exposure of wood mice to TMs in our 399 study. Accumulation patterns in earthworms exposed to soils can be strongly modified by 
400 environmental factors like $\mathrm{pH}$ or organic matter content in soils, ${ }^{57-59}$ which may explain the 401 discrepancy between our results and the literature emphasizing the importance of earthworms on 402 the exposure of mammals to TMs. ${ }^{5,6,60}$ Further, trophic availability of metals accumulated in the 403 various diet items can be different according to their sequestration forms in item tissues, which 404 may also or rather lead to such discrepancies with literature. ${ }^{61}$ Moreover, some invertebrates 405 show high metal accumulation capacity, e.g. snails, isopods, or spiders, ${ }^{62-66}$ whereas others, e.g. 406 Coleoptera, ${ }^{65}$ accumulate less metals in their tissues. For instance, Fritsch et al. ${ }^{54}$ showed that 407 trophic transfer of TMs to blackbirds Turdus merula was less important in habitats linked with a 408 diet based on earthworms than in habitats linked with a diet based on other invertebrates in the 409 surroundings of Metaleurop Nord. They also demonstrated close to or even higher transfer 410 factors (i.e. metal concentration in items divided by metal concentration in soils) of some other 411 invertebrate taxa than earthworms for $\mathrm{Cd}$ and $\mathrm{Pb}$. In the present study, invertebrate items could 412 not be specified further than large categories like "arthropods and mollusks" or "earthworms", 413 and our low taxonomic resolution of invertebrate items could make unclear the role of animal 414 matters on the TM exposure of mammals.

415 Few studies have focused on the relationship between exposure to TMs and diet richness. To 416 our knowledge, only Orłowski et al. ${ }^{7}$ showed significant correlations between the number of 417 items in the diet of nestling rooks Corvus frugilegus and accumulation of TMs in their tissues. In 418 that study, $\mathrm{Pb}$ concentrations in the liver were negatively correlated with the number of vegetal 419 items, while $\mathrm{Cd}$ concentrations were positively correlated with the number of animal items. 420 However, oral exposure to TMs is not always correlated with TM accumulation in tissues. In the 421 study of Godwin et al. ${ }^{67}$ for example, TM concentrations in stomach contents and in tissues of 422 tree swallow Tachycineta bicolor nestlings of the age of 14 days showed no correlation for Ni, 
$423 \mathrm{Sr}$, and $\mathrm{Zn}$, negative correlations for $\mathrm{Mo}$ and $\mathrm{Cu}$, and correlations depending on year and/or 424 tissue for other elements including $\mathrm{Cd}$ and $\mathrm{Pb}$. TM accumulation in animal tissues is determined 425 by several other factors than oral exposure, like species, age, sex and exposure by other routes. ${ }^{68}$ 426 Assimilation of elements via oral route is modulated in intestines by composition of micro- and 427 macro-nutrients, such as iron or calcium. ${ }^{3,69}$ Metal speciation is also another factor affecting 428 intestinal assimilation of TMs. Chunhabundit et al. ${ }^{70}$ reported higher intestinal assimilation of Cd 429 in human intestinal cell from animal-based food than from vegetal-based food. Taking into 430 account those nutrient factors modulating bioavailability of TMs, diet diversity and composition 431 possibly play different roles over the exposure to TMs and the TM accumulation.

432 Even though an important functional role of diet richness on the exposure to TMs is shown 433 here, further investigations should be carried out for elucidating the variation of the oral 434 exposure in space and time. First, metal concentrations in both invertebrates and plants are 435 largely variable according to their organ, size, season, age and/or developmental stage, ${ }^{71,72}$ which 436 are undetectable by DNA based method. Although the metabarcoding is a powerful food 437 identification technique compared to the classical microscopic method or the nitrogen and carbon 438 isotopic approach, accessing information other than taxonomy of items, such as quantity 439 ingested, organs consumed and their TM concentrations, should be included in further studies. 440 Second, mechanisms underlying the relationship between the diet dilution and the diversity of 441 available food in the field remain unclear. The causes and consequences of food composition and 442 food selection depend on the foraging behavior of a given animal, which is also determined by 443 several factors such as balance between nutrients and toxins in food or avoidance of risks by 444 parasites and/or predators. ${ }^{73}$ In our study, occurrences in SCs of Salicaceae and Sapindaceae, two 445 plant families preferentially consumed by wood mice, ${ }^{36}$ were likely to switch along the gradient 
446 of soil contamination: Occurrence in SCs of Salicaceae items decreased, whereas occurrence of

447 Sapindaceae items increased. This result could be due to a change in the preference of wood

448 mice for Salicaceae items along the gradient of soil TM contamination. ${ }^{36}$ The composition of

449 available food in the field and the soil TM contamination may also be considered as to be

450 important factors determining the foraging behavior. Although our finding supported the diet

451 dilution hypothesis, the generality of this phenomenon can depend on several biological and 452 environmental conditions, which should be studied further.

453 To conclude, the level of exposure of small mammals to TMs is influenced not only by the 454 presence of certain items in the diet but also by the diet richness. The functional role of the diet 455 richness on exposure to TMs observed in the present study concurs with the diet dilution 456 hypothesis. Challenging such hypotheses about the functional role of biodiversity on the trophic 457 transfer of pollutants and investigating trait-based mechanisms are possible if ingested food is 458 identified in details. Although the metabarcoding approach allows identifying the taxonomy of 459 food under field conditions, associating life history traits and chemical composition of each item 460 and clarifying mechanisms of foraging behavior of animals will improve chemical risk 461 assessment in wildlife. Further perspectives also deal with the quantification of trophic links to 462 address the functional significance of trophic interactions for the transfer of matter, energy, and 463 essential elements versus the transfer of toxicants, and the evolutionary trade-offs between 464 acquiring nutrients but being exposed to toxic substances. 
466 Figure 1. Conditional inference trees (CIT) for (a) the exposure to $\mathrm{Cd}$ and (b) the exposure to 467 Zn, i.e. residuals of linear model between logarithmically-transformed concentrations of TMs in 468 stomach content and in soils $\left(\mu \mathrm{g} \mathrm{g}^{-1} \mathrm{DM}\right)$. Partitioning variables significantly selected for splits 469 (univariate $p$-value $<0.05$ ) are listed in inner nods (represented as ovals) with $p$-value and their 470 splitting criteria are listed on the lines connecting variables. Presence or absence of a given item

471 in stomach content of wood mice is represented by "yes" or " $n o$ ", respectively. Boxplot in 472 terminal node describes the residuals of the given TM for each final classification group with 473 sample size, and median of the classification group is mentioned below.

(a)

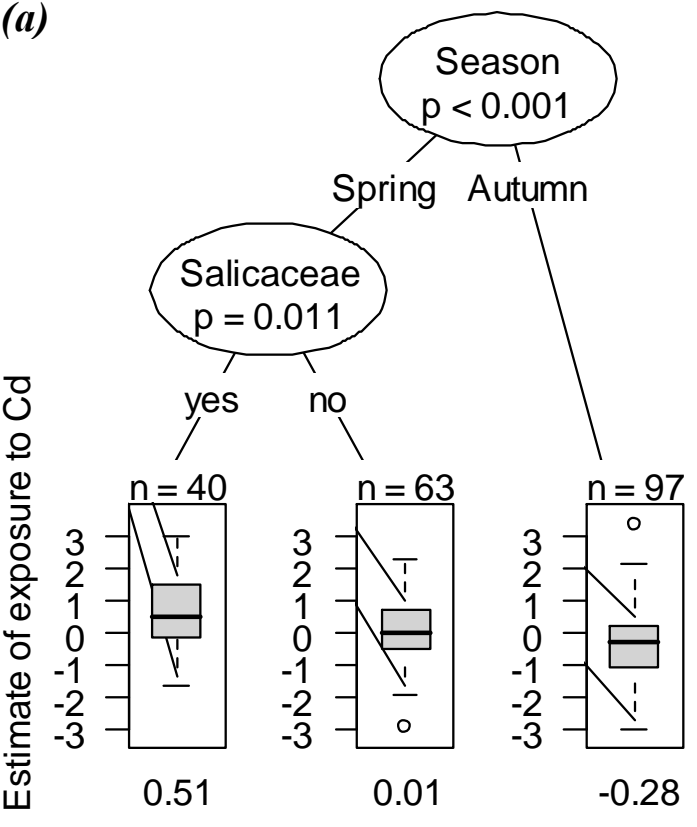

(b)
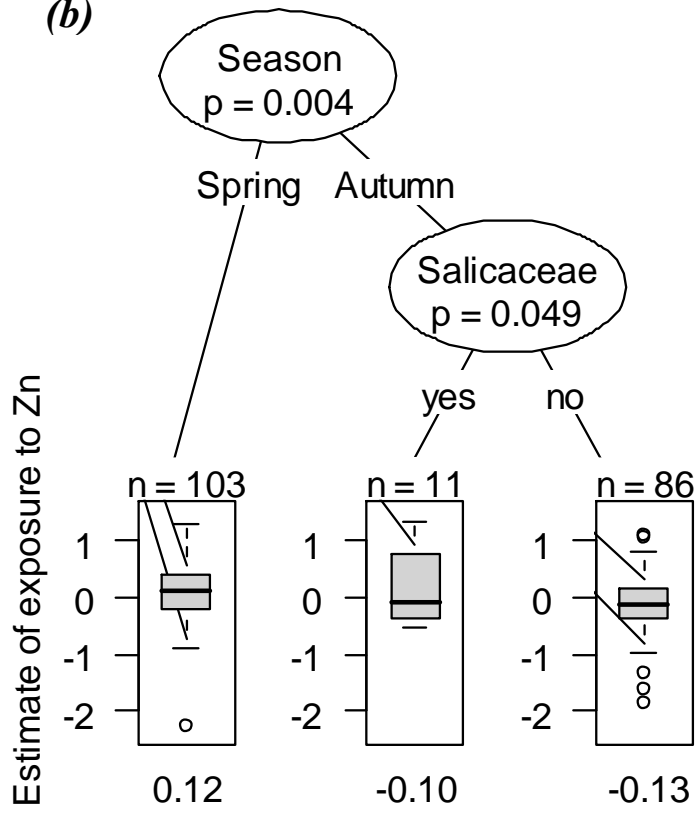
476 Figure 2. (a) Exposure of the wood mice to $\mathrm{Cd}$ along the gradient of proportion of Salicaceae

477 items' sequence number in stomach content, considered as a proxy of biomass consumed and (b)

478 the proportion of Salicaceae items' sequences along the gradient of diet richness of plant. Plotted

479 points indicate stomach contents. Values predicted from our models are indicated by lines.

480 Different color lines represent different sites (random effect). Variation explained by fixed and

481 random effects are respectively explained by marginal and conditional $R^{2}\left(R_{m}^{2}\right.$ and $\left.R_{c}^{2}\right)$ in the 482 figures.

(a)

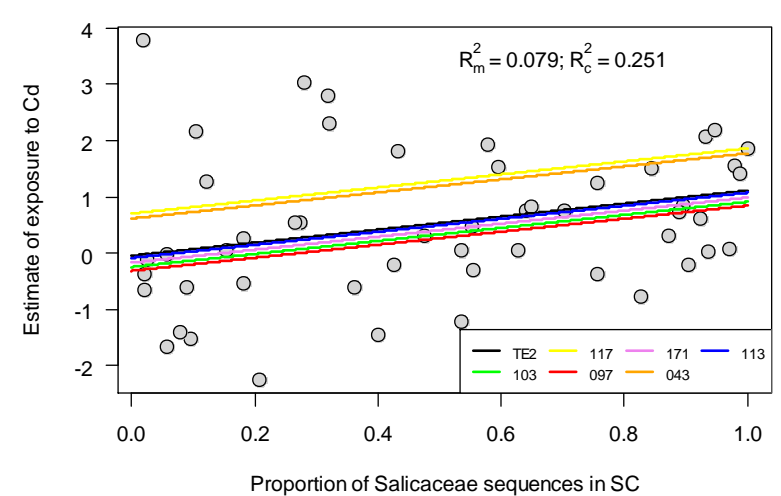

(b)

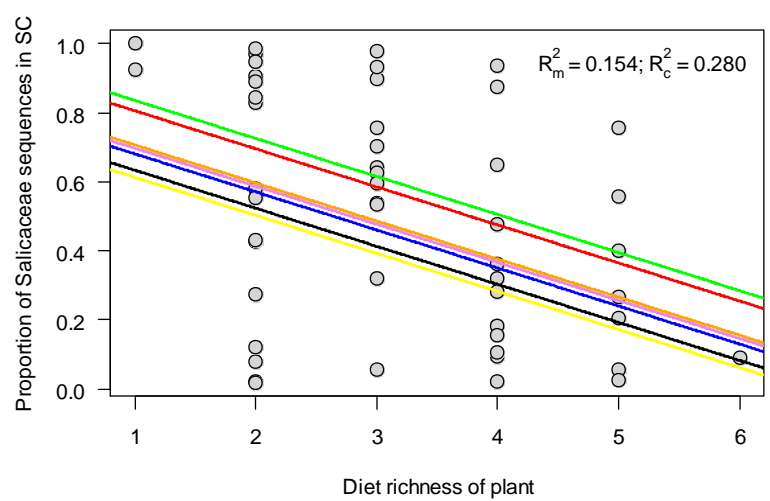


485 Figure 3. Model-based recursive partitioning (MOB) on mixed linear models for the exposure to 486 TMs, i.e. residuals of linear model between logarithmically-transformed concentrations of TMs 487 in stomach content and in soils $\left(\mu \mathrm{g} \mathrm{g}^{-1}\right)$, with respect to either three diet richness of plant, 488 arthropod and earthworm MOTUs or the sum of them (i.e. total diet richness): exposure to Cd 489 with respect to the total diet richness (a) and to the three diet richness (b), exposure to $\mathrm{Zn}$ with 490 respect to the total diet richness (c) and to the three diet richness (d). Partitioning variables 491 significantly selected for splits (univariate $p$-value $<0.05$ ) are listed in inner nods (represented as 492 ovals) with p-value and their splitting criteria are listed on the lines connecting variables. 493 Presence or absence of a given item in stomach content of wood mice is represented by "yes" or 494 "no", respectively. Scatter plots in terminal nodes describe relationships between the response 495 variable (y axis) and each explanatory variable (x axes, from bottom line to top, earthworm, 496 arthropod and plant diet richness). An asterisk (*) denotes significant correlation by type III 497 ANOVA. $\mathrm{R}^{2}$ of the linear model for partitioned data $\left(\mathrm{R}^{2}{ }_{\text {node }}\right)$ is mentioned below only if 498 significant correlation was observed. The variation explained by the fixed and the random effects $499\left(\mathrm{R}_{\mathrm{m}}^{2}\right.$ and $\mathrm{R}^{2}$, respectively) are mentioned at the top of the figure. 
(a)

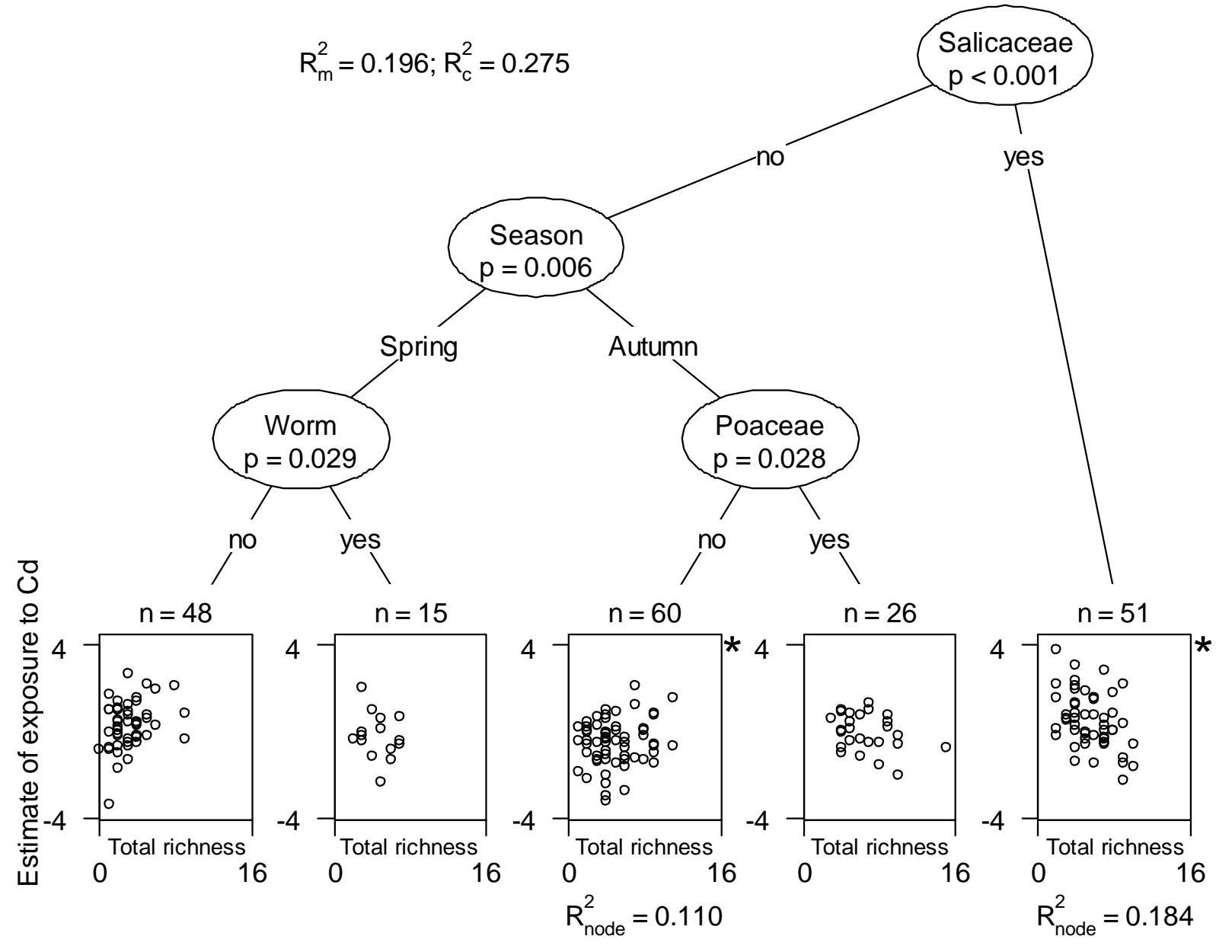




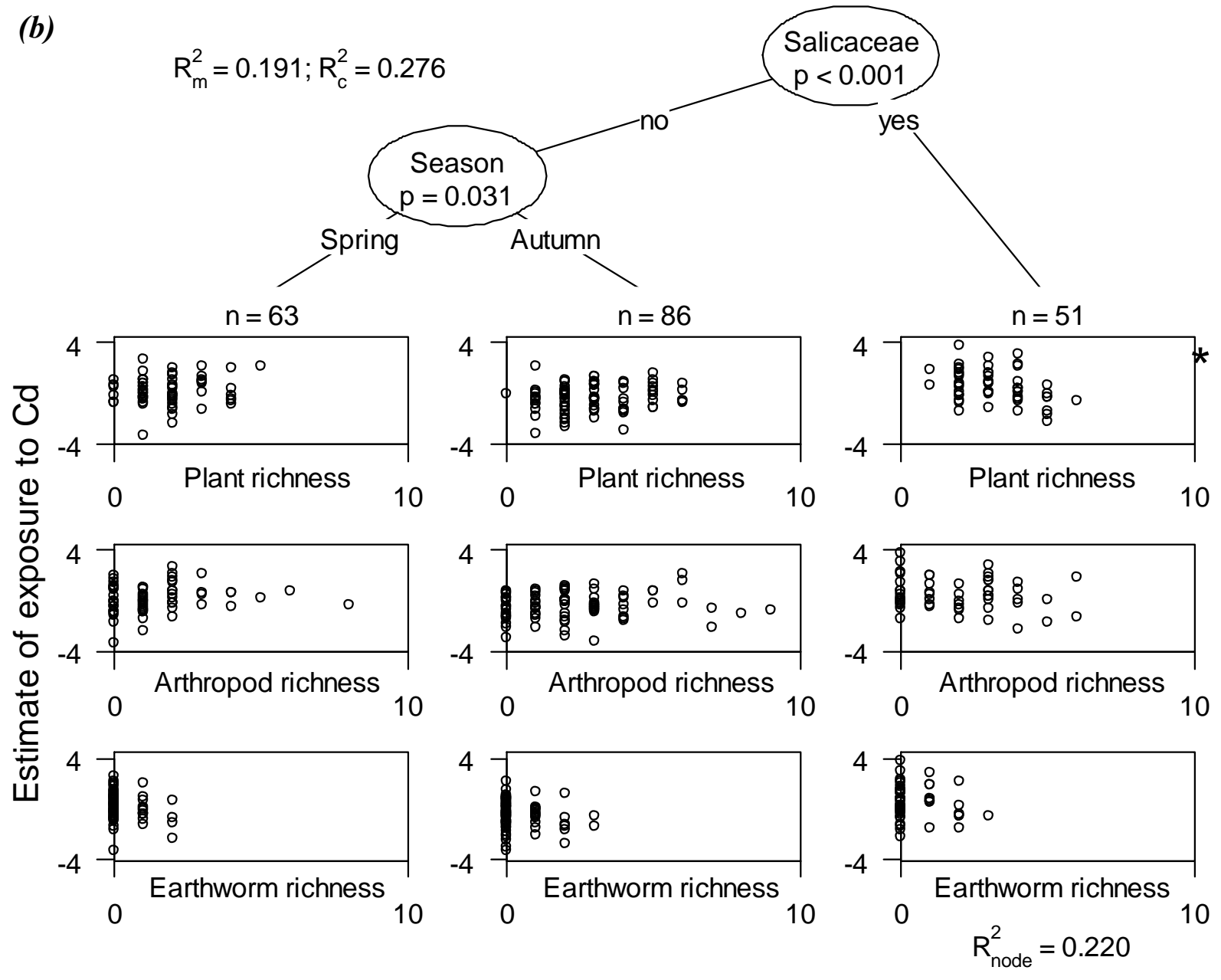


(c)

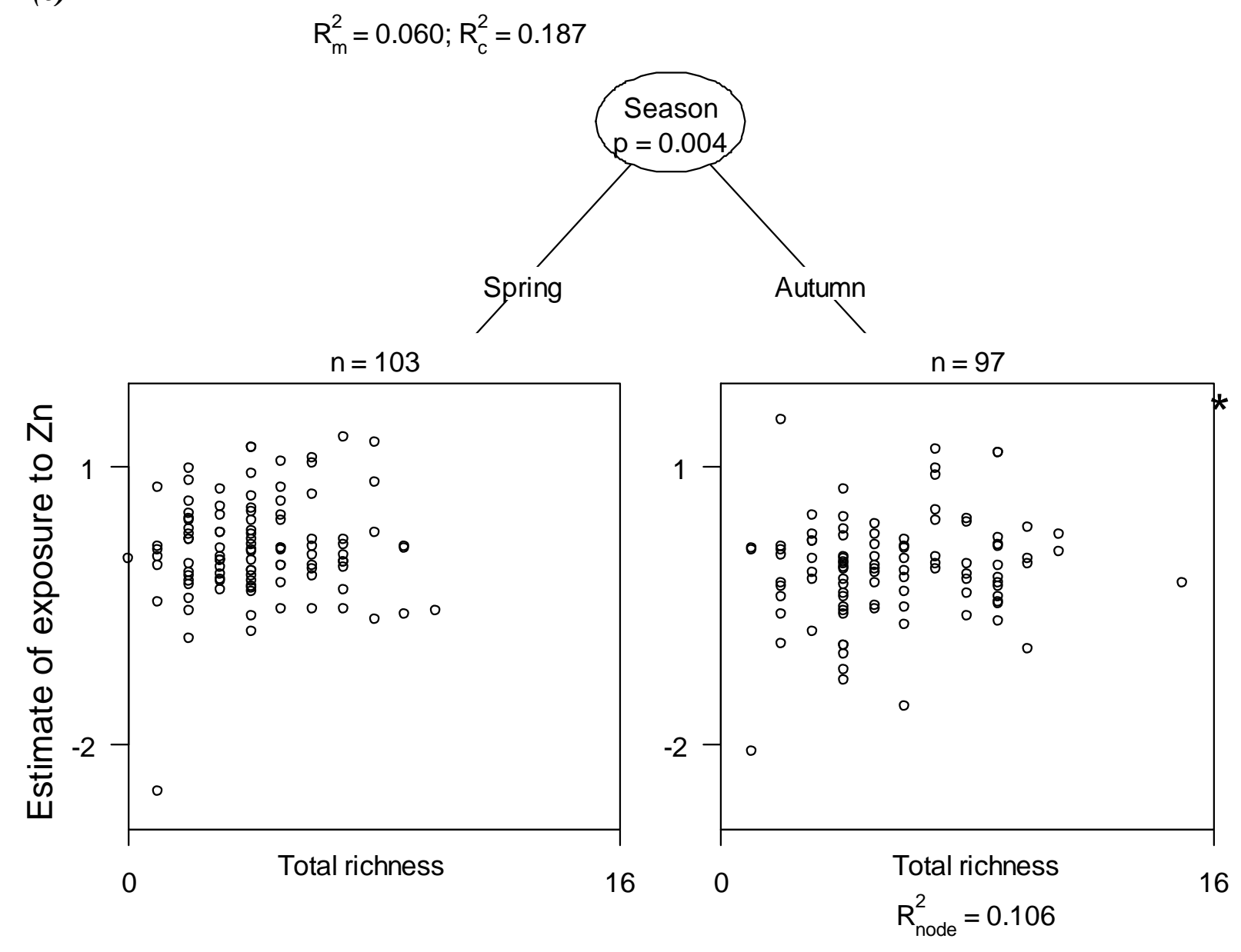




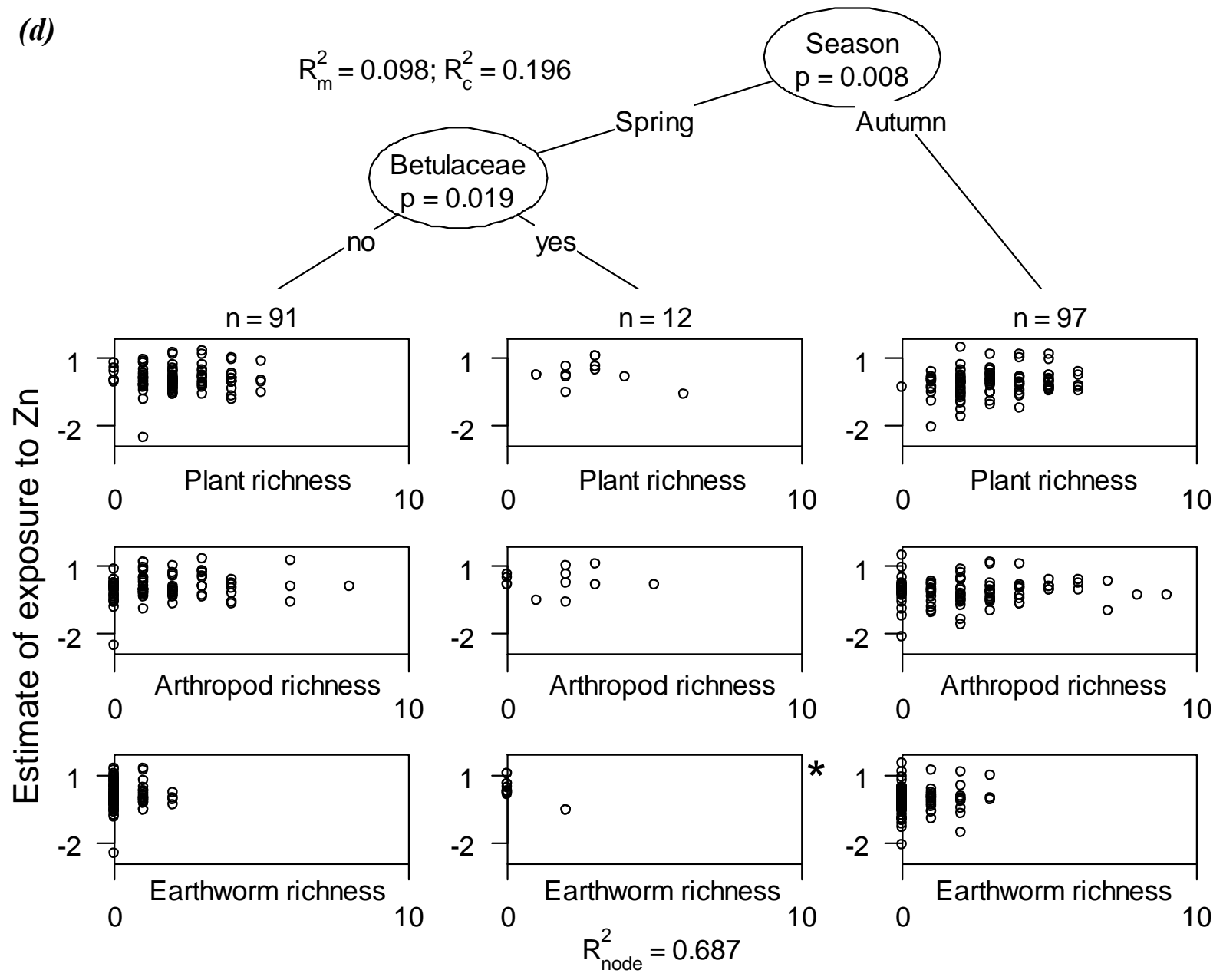




\section{Supporting Information}

505 Figure S1: Relationships between concentrations of TMs in SCs and in soils.

506 Figure S2: Conditional inference tree for frequency of occurrence of Salicaceae, Sapindaceae,

507 Fagaceae and Oleaceae items in SCs of wood mice.

508 Figure S3: Predicted probabilities for occurrence of items consumed in SCs along a gradient of

509 Cd concentration in soils by generalized linear models.

510 Figure S4: Correlation matrix for TM concentrations in soils and dietary richness of plant, 511 arthropod and earthworm MOTUs.

512 Figure S5: Concentrations of the three TMs in SCs of wood mice and exposure to the TMs in 513 spring and autumn.

514 Figure S6: Significant differences in exposure to TMs between the presence/absence of plants 515 items in SCs.

516 Table S1: Information about each study site about TM contamination and landscape dominant 517 habitats.

518 Table S2: List of primers used for identifying food.

519 Table S3: List of frequency of occurrence of items in SCs.

521 AUTHOR INFORMATION

\section{Corresponding Author}


523 * Phone number: +33 (0)3 816665 98; E-mail address: shinji.ozaki@univ-fcomte.fr.

\section{$524 \quad$ Notes}

$525 \quad$ \# both authors contributed equally to supervising this work

\section{ACKNOWLEDGMENT}

527 This study was financially supported by the project BIOTROPH, co-funded by the Agence De 528 l'Environnement et de la Maîtrise de l'Energie (ADEME; contract No.1172C0030) and the 529 Conseil Régional du Nord-Pas de Calais (CRNPC; orders No.12000921 and 14001044; joint call 530 with the Fondation pour la Recherche sur la Biodiversité). The first author was financially 531 supported by a grant from the Conseil Régional de Franche-Comté (contract No. 2015C-06107). 532 The authors gratefully thank Cécile Grand from ADEME for fruitful scientific discussion. We 533 also thank Eva Bellemain and Alice Valentini from SPYGEN Company for their help in DNA 534 analyses and interpretations. We finally thank Nadia Crini, Caroline Amiot, Dominique Rieffel 535 and Anne-Sophie Prudent for their precious assistance.

537 AUTHOR CONTRIBUTIONS

538 F.R. and R.S. conceived the study; S.O., R.S., C.F. and F.R. designed the study; R.S., C.F., F.M., 539 T.C. and F.R. performed field samplings and laboratory treatments; B.V. performed 540 bioinformatics treatments; S.O. performed the statistical analyses; S.O., F.R., R.S. and C.F. 541 interpreted the results. S.O. wrote the manuscript under the supervision of all authors.

\section{REFERENCES}

544 (1) Madrid, L. "Heavy Metals": Reminding a Long-Standing and Sometimes Forgotten 
Controversy.

Geoderma

2010,

155

$(1-2)$,

$128-129$.

https://doi.org/10.1016/j.geoderma.2009.11.031.

(2) Walker, C. H.; Hopkin, S. P.; Sibly, R. M.; Peakall, D. B. Principles of Ecotoxicology, 4th ed.; CRC Press: Boca Raton, 2012.

(3) Shore, R. F.; Rattner, B. A. Ecotoxicology of Wild Mammals; Ecotoxicology and

(4) Hamers, T.; van den Berg, J. H. J.; van Gestel, C. A. M.; van Schooten, F.-J.; Murk, A. J.

Risk Assessment of Metals and Organic Pollutants for Herbivorous and Carnivorous Small Mammal Food Chains in a Polluted Floodplain (Biesbosch, The Netherlands). Environ.

(7) Orłowski, G.; Kamiński, P.; Kasprzykowski, Z.; Zawada, Z. Relationships between

Pollut. 2006, 144 (2), 581-595. https://doi.org/10.1016/j.envpol.2006.01.020.

5) Rogival, D.; Scheirs, J.; Blust, R. Transfer and Accumulation of Metals in a Soil-dietwood Mouse Food Chain along a Metal Pollution Gradient. Environ. Pollut. 2007, 145 (2), 516-528. https://doi.org/10.1016/j.envpol.2006.04.019.

6) van den Brink, N.; Lammertsma, D.; Dimmers, W.; Boerwinkel, M.-C.; van der Hout, A. Effects of Soil Properties on Food Web Accumulation of Heavy Metals to the Wood Mouse (Apodemus Sylvaticus). Environ. Pollut. 2010, 158 (1), 245-251. https://doi.org/10.1016/j.envpol.2009.07.013.

Stomach Content and Concentrations of Essential and Non-Essential Elements in Tissues of Omnivorous Nestling Rooks Corvus Frugilegus: Is the Size and Composition of Stomach Content Relevant. Folia Zool. 2013, 62, 282-289.

(8) Valentini, A.; Pompanon, F.; Taberlet, P. DNA Barcoding for Ecologists. Trends Ecol. Evol. 2009, 24 (2), 110-117. https://doi.org/10.1016/j.tree.2008.09.011. 
568 (9) Pompanon, F.; Deagle, B. E.; Symondson, W. O. C.; Brown, D. S.; Jarman, S. N.; Taberlet, P. Who Is Eating What: Diet Assessment Using next Generation Sequencing. Mol. Ecol. 2012, 21 (8), 1931-1950. https://doi.org/10.1111/j.1365-294X.2011.05403.x.

(10) Taberlet, P.; Coissac, E.; Hajibabaei, M.; Rieseberg, L. H. Environmental DNA. Mol. Ecol. 2012, $21(8), 1789-1793$.

(11) Taberlet, P.; Coissac, E.; Pompanon, F.; Brochmann, C.; Willerslev, E. Towards nextGeneration Biodiversity Assessment Using DNA Metabarcoding. Mol. Ecol. 2012, 21 (8), $2045-2050$.

(12) Bohmann, K.; Evans, A.; Gilbert, M. T. P.; Carvalho, G. R.; Creer, S.; Knapp, M.; Yu, D. W.; de Bruyn, M. Environmental DNA for Wildlife Biology and Biodiversity Monitoring. Trends Ecol. Evol. 2014, 29 (6), 358-367. https://doi.org/10.1016/j.tree.2014.04.003.

(13) Soininen, E. M.; Valentini, A.; Coissac, E.; Miquel, C.; Gielly, L.; Brochmann, C.; Brysting, A. K.; Sønstebø, J. H.; Ims, R. A.; Yoccoz, N. G. ; Taberlet, P. Analysing Diet of Small Herbivores: The Efficiency of DNA Barcoding Coupled with High-Throughput Pyrosequencing for Deciphering the Composition of Complex Plant Mixtures. Front. Zool. 2009, 6 (1), 16. https://doi.org/10.1186/1742-9994-6-16.

(14) Bohmann, K.; Monadjem, A.; Lehmkuhl Noer, C.; Rasmussen, M.; Zeale, M. R. K.; Clare, E.; Jones, G.; Willerslev, E.; Gilbert, M. T. P. Molecular Diet Analysis of Two African Free-Tailed Bats (Molossidae) Using High Throughput Sequencing. PLoS ONE 2011, 6 (6), e21441. https://doi.org/10.1371/journal.pone.0021441.

(15) Ait Baamrane, M. A.; Shehzad, W.; Ouhammou, A.; Abbad, A.; Naimi, M.; Coissac, E.; Taberlet, P.; Znari, M. Assessment of the Food Habits of the Moroccan Dorcas Gazelle in M'Sabih Talaa, West Central Morocco, Using the trnL Approach. PLoS ONE 2012, 7 (4), 
e35643. https://doi.org/10.1371/journal.pone.0035643.

592

593

594

595

596

597

598

599

600

601

602

603

604

605

606

607

608

609

610

611

612

613

(16) De Barba, M.; Miquel, C.; Boyer, F.; Mercier, C.; Rioux, D.; Coissac, E.; Taberlet, P. DNA Metabarcoding Multiplexing and Validation of Data Accuracy for Diet Assessment: Application to Omnivorous Diet. Mol. Ecol. Resour. 2013, 14 (2), 306-323. https://doi.org/10.1111/1755-0998.12188.

(17) Soininen, E. M.; Ravolainen, V. T.; Bråthen, K. A.; Yoccoz, N. G.; Gielly, L.; Ims, R. A. Arctic Small Rodents Have Diverse Diets and Flexible Food Selection. PLoS ONE 2013, 8 (6), e68128. https://doi.org/10.1371/journal.pone.0068128.

(18) Watts, C. H. S. The Foods Eaten by Wood Mice (Apodemus Sylvaticus) and Bank Voles (Clethrionomys Glareolus) in Wytham Woods, Berkshire. J. Anim. Ecol. 1968, 37 (1), 2541.

(19) Butet, A. Régime Alimentaire D'une Population de Mulots Sylvestres (Apodemus Sylvaticus L., 1758), Dans Une Lande Xéro-Mésophile En Cours de Recolonisation Végétale. Bull. Ecol. 1986, 17, 21-37.

(20) Rogers, L. M.; Gorman, M. L. The Diet of the Wood Mouse Apodemus Sylvaticus on Setaside Land. J. Zool. 1995, 235 (1), 77-83.

(21) Abt, K. F.; Bock, W. F. Seasonal Variations of Diet Composition in Farmland Field Mice Apodemus Spp. and Bank Voles Clethrionomys Glareolus. Acta Theriol. (Warsz.) 1998, 43 (4), 379-389.

(22) Quéré, J.-P.; Le Louarn, H. Les rongeurs de France: Faunistique et biologie, 2nd ed.; Quae: Versailles, 2011.

(23) González, X. I.; Aboal, J. R.; Fernández, J. A.; Carballeira, A. Considerations on the Sample Size of Wood Mice Used to Biomonitor Metals. Sci. Total Environ. 2006, 366 (2- 
3), 910-914. https://doi.org/10.1016/j.scitotenv.2005.10.003.

615

616

617

618

619

620

621

622

623

624

625

626

627

628

629

630

631

632

633

634

635

636

(24) Sánchez-Chardi, A.; Peñarroja-Matutano, C.; Ribeiro, C. A. O.; Nadal, J. Bioaccumulation of Metals and Effects of a Landfill in Small Mammals. Part II. The Wood Mouse, Apodemus Sylvaticus. Chemosphere 2007, $70 \quad$ (1), 101-109. https://doi.org/10.1016/j.chemosphere.2007.06.047.

(25) Tête, N.; Durfort, M.; Rieffel, D.; Scheifler, R.; Sánchez-Chardi, A. Histopathology Related to Cadmium and Lead Bioaccumulation in Chronically Exposed Wood Mice, Apodemus Sylvaticus, around a Former Smelter. Sci. Total Environ. 2014, 481, 167-177. https://doi.org/10.1016/j.scitotenv.2014.02.029.

(26) Sterckeman, T.; Douay, F.; Proix, N.; Fourrier, H.; Perdrix, E. Assessment of the Contamination of Cultivated Soils by Eighteen Trace Elements around Smelters in the North of France. Water. Air. Soil Pollut. 2002, 135 (1-4), 173-194.

(27) Douay, F.; Pruvot, C.; Roussel, H.; Ciesielski, H.; Fourrier, H.; Proix, N.; Waterlot, C. Contamination of Urban Soils in an Area of Northern France Polluted by Dust Emissions of Two Smelters. Water. Air. Soil Pollut. 2008, 188 (1-4), 247-260. https://doi.org/10.1007/s11270-007-9541-7.

(28) Douay, F.; Pruvot, C.; Waterlot, C.; Fritsch, C.; Fourrier, H.; Loriette, A.; Bidar, G.; Grand, C.; de Vaufleury, A.; Scheifler, R. Contamination of Woody Habitat Soils around a Former Lead Smelter in the North of France. Sci. Total Environ. 2009, 407 (21), 5564-5577. https://doi.org/10.1016/j.scitotenv.2009.06.015.

(29) Waterlot, C.; Pruvot, C.; Bidar, G.; Fritsch, C.; De Vaufleury, A.; Scheifler, R.; Douay, F. Prediction of Extractable $\mathrm{Cd}, \mathrm{Pb}$ and $\mathrm{Zn}$ in Contaminated Woody Habitat Soils Using a Change Point Detection Method. Pedosphere 2016, 26 (3), 282-298. 
https://doi.org/10.1016/S1002-0160(15)60043-1.

638

639

640

641

642

643

644

645

646

647

648

649

650

651

652

653

654

655

656

657

658

659

(30) Fritsch, C.; Giraudoux, P.; Cœurdassier, M.; Douay, F.; Raoul, F.; Pruvot, C.; Waterlot, C.; Vaufleury, A. de; Scheifler, R. Spatial Distribution of Metals in Smelter-Impacted Soils of Woody Habitats: Influence of Landscape and Soil Properties, and Risk for Wildlife. Chemosphere 2010, 81 (2), 141-155. https://doi.org/10.1016/j.chemosphere.2010.06.075.

(31) Fritsch, C.; Cœurdassier, M.; Giraudoux, P.; Raoul, F.; Douay, F.; Rieffel, D.; Vaufleury, A. de; Scheifler, R. Spatially Explicit Analysis of Metal Transfer to Biota: Influence of Soil Contamination and Landscape. PLoS ONE 2011, $6 \quad$ (5), e20682. https://doi.org/10.1371/journal.pone.0020682.

(32) Taberlet, P.; Coissac, E.; Pompanon, F.; Gielly, L.; Miquel, C.; Valentini, A.; Vermat, T.; Corthier, G.; Brochmann, C.; Willerslev, E. Power and Limitations of the Chloroplast $\operatorname{trn} \mathrm{L}$ (UAA) Intron for Plant DNA Barcoding. Nucleic Acids Res. 2007, 35 (3), e14. https://doi.org/10.1093/nar/gk1938.

(33) Bienert, F.; De Danieli, S.; Miquel, C.; Coissac, E.; Poillot, C.; Brun, J.-J.; Taberlet, P. Tracking Earthworm Communities from Soil DNA. Mol. Ecol. 2012, 21 (8), 2017-2030. https://doi.org/10.1111/j.1365-294X.2011.05407.x.

(34) Schloss, P. D.; Westcott, S. L.; Ryabin, T.; Hall, J. R.; Hartmann, M.; Hollister, E. B.; Lesniewski, R. A.; Oakley, B. B.; Parks, D. H.; Robinson, C. J.; Sahl, J. W.; Stres, B.; Thallinger, G. G.; Van Horn, D. J.; Weber, C. F. Introducing Mothur: Open-Source, Platform-Independent, Community-Supported Software for Describing and Comparing Microbial Communities. Appl. Environ. Microbiol. 2009, 75 (23), 7537-7541. https://doi.org/10.1128/AEM.01541-09.

(35) Deagle, B. E.; Thomas, A. C.; Shaffer, A. K.; Trites, A. W.; Jarman, S. N. Quantifying 
Sequence Proportions in a DNA-Based Diet Study Using Ion Torrent Amplicon

Sequencing: Which Counts Count? Mol. Ecol. Resour. 2013, 13 (4), 620-633. https://doi.org/10.1111/1755-0998.12103.

(36) Ozaki, S.; Fritsch, C.; Valot, B.; Mora, F.; Cornier, T.; Scheifler, R.; Raoul, F. Does

Pollution Influence Small Mammal Diet in the Field? A Metabarcoding Approach in a Generalist Consumer. Mol. Ecol. 2018, 27 (18), 3700-3713. https://doi.org/10.1111/mec.14823.

37) Beyer, W. N.; Connor, E. E.; Gerould, S. Estimates of Soil Ingestion by Wildlife. J. Wildl. Manag. 1994, 58 (2), 375-382. https://doi.org/10.2307/3809405.

(38) Smith, K. M.; Abrahams, P. W.; Dagleish, M. P.; Steigmajer, J. The Intake of Lead and Associated Metals by Sheep Grazing Mining-Contaminated Floodplain Pastures in MidWales, UK: I. Soil Ingestion, Soil-metal Partitioning and Potential Availability to Pasture Herbage and Livestock. Sci. Total Environ. 2009, 407 (12), 3731-3739. https://doi.org/10.1016/j.scitotenv.2009.02.032.

(39) Hothorn, T.; Hornik, K.; Zeileis, A. Unbiased Recursive Partitioning: A Conditional Inference Framework. J. Comput. Graph. Stat. 2006, 15 (3), 651-674.

(40) Strasser, H.; Weber, C. On the Asymptotic Theory of Permutation Statistics. Math. Methods Stat. 1999, 8, 220-250.

(41) Deiner, K.; Bik, H. M.; Mächler, E.; Seymour, M.; Lacoursière-Roussel, A.; Altermatt, F.; Creer, S.; Bista, I.; Lodge, D. M.; de Vere, N.; Pfrender, M. E.; Bernatchez, L. Environmental DNA Metabarcoding: Transforming How We Survey Animal and Plant Communities. Mol. Ecol. 2017, 26 (21), 5872-5895. https://doi.org/10.1111/mec.14350.

(42) Nakagawa, S.; Schielzeth, H. A General and Simple Method for Obtaining $R^{2}$ from 
Generalized Linear Mixed-Effects Models. Methods Ecol. Evol. 2013, 4 (2), 133-142.

684

685

686

687

688

689

690

691

692

693

694

695

696

697

698

699

700

701

702

703

704

705

https://doi.org/10.1111/j.2041-210x.2012.00261.x.

(43) Zuur, A. F. Mixed Effects Models and Extensions in Ecology with R; Statistics for biology and health; Springer: New York, 2009.

(44) Zeileis, A.; Hothorn, T.; Hornik, K. Model-Based Recursive Partitioning. J. Comput. Graph. Stat. 2008, 17 (2), 492-514.

(45) Zeileis, A. A Unified Approach to Structural Change Tests Based on ML Scores, F Statistics, and OLS Residuals. Econom. Rev. 2005, 24 (4), 445-466.

(46) Zeileis, A.; Hornik, K. Generalized M-Fluctuation Tests for Parameter Instability. Stat. Neerlandica 2007, 61 (4), 488-508.

(47) Fokkema, M.; Smits, N.; Zeileis, A.; Hothorn, T.; Kelderman, H. Detecting TreatmentSubgroup Interactions in Clustered Data with Generalized Linear Mixed-Effects Model Trees. Working Paper 2015-10. Working Papers in Economics and Statistics, Research Platform Empirical and Experimental Economics, Universität Innsbruck. 2015, p http://EconPapers.RePEc.org/RePEc:inn:wpaper:2015-10.

(48) Pulford, I. D.; Watson, C. Phytoremediation of Heavy Metal-Contaminated Land by Trees-a Review. Environ. Int. 2003, 29 (4), 529-540. https://doi.org/10.1016/S01604120(02)00152-6.

(49) Nolet, B. A.; Dijkstra, V. A.; Heidecke, D. Cadmium in Beavers Translocated from the Elbe River to the Rhine/Meuse Estuary, and the Possible Effect on Population Growth Rate. Arch. Environ. Contam. Toxicol. 1994, 27 (2), 154-161.

(50) Brekken, A.; Steinnes, E. Seasonal Concentrations of Cadmium and Zinc in Native Pasture Plants: Consequences for Grazing Animals. Sci. Total Environ. 2004, 326 (1-3), 181-195. 
https://doi.org/10.1016/j.scitotenv.2003.11.023.

(51) Migeon, A.; Richaud, P.; Guinet, F.; Chalot, M.; Blaudez, D. Metal Accumulation by Woody Species on Contaminated Sites in the North of France. Water. Air. Soil Pollut. 2009, 204, 89-101. https://doi.org/10.1007/s11270-009-0029-5.

(52) Boyd, R. S. Hyperaccumulation as a Plant Defensive Strategy. In Plants that hyperaccumulate heavy metals; Brooks, R. R., Ed.; CAB International: Oxford, 1998; pp 181-201.

(53) Martens, S. N.; Boyd, R. S. The Defensive Role of Ni Hyperaccumulation by Plants: A Field Experiment. Am. J. Bot. 2002, 89 (6), 998-1003.

(54) Fritsch, C.; Coeurdassier, M.; Faivre, B.; Baurand, P.-E.; Giraudoux, P.; van den Brink, N. W.; Scheifler, R. Influence of Landscape Composition and Diversity on Contaminant Flux in Terrestrial Food Webs: A Case Study of Trace Metal Transfer to European Blackbirds Turdus Merula. Sci. Total Environ. 2012, 432, 275-287. https://doi.org/10.1016/j.scitotenv.2012.06.004.

(55) Mourier, B.; Fritsch, C.; Dhivert, E.; Gimbert, F.; Cœurdassier, M.; Pauget, B.; Vaufleury, A. de; Scheifler, R. Chemical Extractions and Predicted Free Ion Activities Fail to Estimate Metal Transfer from Soil to Field Land Snails. Chemosphere 2011, 85 (6), 10571065. https://doi.org/10.1016/j.chemosphere.2011.07.035.

(56) Nahmani, J.; Hodson, M. E.; Black, S. A Review of Studies Performed to Assess Metal Uptake by Earthworms. Environ. Pollut. 2007, 145 (2), 402-424. https://doi.org/10.1016/j.envpol.2006.04.009.

(57) Janssen, R.; Posthuma, L.; Baerselman, R.; Den Hollander, H. A.; Van Veen, R. P.; Peijnenburg, W. J. Equilibrium Partitioning of Heavy Metals in Dutch Field Soils. II. 
Prediction of Metal Accumulation in Earthworms. Environ. Toxicol. Chem. 1997, 16 (12), 2479-2488.

731

732

733

734

735

736

737

738

739

740

741

742

743

744

745

746

747

748

749

750

751

(58) Morgan, J. E.; Morgan, A. J. Earthworms as Biological Monitors of Cadmium, Copper, Lead and Zinc in Metalliferous Soils. Environ. Pollut. 1988, 54 (2), 123-138. https://doi.org/10.1016/0269-7491(88)90142-X.

(59) Nannoni, F.; Rossi, S.; Protano, G. Soil Properties and Metal Accumulation by Earthworms in the Siena Urban Area (Italy). Appl. Soil Ecol. 2014, 77, 9-17. https://doi.org/10.1016/j.apsoil.2014.01.004.

(60) Ma, W. Heavy Metal Accumulation in the Mole, Talpa Europea, and Earthworms as an Indicator of Metal Bioavailability in Terrestrial Environments. Bull. Environ. Contam. Toxicol. 1987, 39 (6), 933-938.

(61) Vijver, M. G.; van Gestel, C. A. M.; Lanno, R. P.; van Straalen, N. M.; Peijnenburg, W. J. G. M. Internal Metal Sequestration and Its Ecotoxicological Relevance: A Review. Environ. Sci. Technol. 2004, 38 (18), 4705-4712. https://doi.org/10.1021/es040354g.

(62) Hopkin, S. P. Ecophysiology of Metals in Terrestrial Invertebrates; Elsevier Applied Science: London, 1989.

(63) Janssen, M. P. M.; Bruins, A.; De Vries, T. H.; Van Straalen, N. M. Comparison of Cadmium Kinetics in Four Soil Arthropod Species. Arch. Environ. Contam. Toxicol. 1991, $20(3), 305-312$.

(64) Dallinger, R. Strategies of Metal Detoxification in Terrestrial Invertebrates. In Ecotoxicology of Metals in Invertebrates; Dallinger, R., Rainbow, P. S., Eds.; Lewis Publishers: London, 1993; pp 245-280.

(65) Heikens, A.; Peijnenburg, W. J. G. M.; Hendriks, A. J. Bioaccumulation of Heavy Metals 
in Terrestrial Invertebrates. Environ. Pollut. 2001, 113, 385-393.

753 (66) Hendrickx, F.; Maelfait, J.-P.; Langenbick, F. Absence of Cadmium Excretion and High

(67) Godwin, C. M.; Smits, J. E. G.; Barclay, R. M. R. Metals and Metalloids in Nestling Tree Swallows and Their Dietary Items near Oilsands Mine Operations in Northern Alberta.

Sci. Total Environ. 2016, 562, 714-723. https://doi.org/10.1016/j.scitotenv.2016.04.069.

(68) Gall, J. E.; Boyd, R. S.; Rajakaruna, N. Transfer of Heavy Metals through Terrestrial Food Webs: A Review. Environ. Monit. Assess. 2015, 187 (4). https://doi.org/10.1007/s10661015-4436-3.

(69) Nordberg, G. F.; Fowler, B. A.; Nordberg, M.; Friberg, L. T. Handbook on the Toxicology of Metals, 4th ed.; Academic Press: London, 2014.

(70) Chunhabundit, R.; Srianujata, S.; Bunyaratvej, A.; Kongkachuichai, R.; Satayavivad, J.; Kaojarern, S. Cadmium Bioavailability from Vegetable and Animal-Based Foods Assessed with in Vitro Digestion/Caco-2 Cell Model. J. Med. Assoc. Thai. 2011, 94 (2), 164-171.

(71) Hare, L. Aquatic Insects and Trace Metals: Bioavailability, Bioaccumulation and Toxicity. Crit. Rev. Toxicol. 1992, 22, 327-369.

(72) Kabata-Pendias, A. Trace Elements in Soils and Plants, 4th ed.; CRC Press: Boca Raton, 2011.

(73) Singer, M. S.; Bernays, E. A. Understanding Omnivory Needs a Behavioral Perspective. Ecology 2003, 84 (10), 2532-2537. 